\title{
Evidence in a post-truth world: nurses and critical thinking
}

We live in interesting times. Earlier generations experienced a greater degree of certainty in the social world, people 'knew their place' and identified strongly with their communities. Grand narratives, of values and beliefs, religion and politics, conferred a degree of cohesion, but no greater, and probably less, equity or equality. The current age is more fractured and uncertain. Many big truths of the post-war world are under siege: pax Americana is challenged on all sides, not least by its leader and North Korea; Brexit threatens the dismemberment of the European Union; consumerism, shaken by the Global Financial Crisis, appears to have regrouped and be lining up for a rerun. Little wonder, perhaps, if science, another big truth, seems to have a bulls-eye on its back. In the big story of our age - climate change - evidence struggles for air time and support in the face of alternative truths that deny anything other than climatic business as usual or random variation; that promote fossil fuels (coal), rescind and renege on policies and agreements to limit carbon emissions. While scientists labour to fact-check, post-truth rolls on, swamping the media and morphing the message.

Is evidence enough? It would seem not - but as long ago as Aristotle we recognised that, whilst knowledge is power, knowledge alone does not sell. Evidence ('logos') contributes but the power of persuasion is more potent with 'ethos' (the credibility and personal power of the narrator) and 'pathos' (the emotional tug at the heart).

In nursing we have the example of our contribution to patient outcomes. A substantial, rigorous evidence base over nearly 30 years links adequate numbers of skilled and qualified nurses with better patient outcomes. Yet the dominant story continues so often of 'waste' and a search for 'efficiencies' with politically and fiscally driven human resource policies. We've seen this story lead to Staffordshire (Francis, 2013), to a nursing workforce diluted in numbers and skills, with patients suffering. This was a scandal and the public was rightly scandalised but where was the public acknowledgement that evidence was denied to set up this situation? So where do we go with this? 
Critical thinking is a key characteristic and core skill of nursing, an essential element of our image of ourselves and our profession. At the same time our culture is preferentially oral: we look to 'experts' (locally respected colleagues) as preferred sources of knowledge. We could put these together, and apply our critical thinking not just for nursing decisions but also to messages coming to us through social and mainstream media.

As trusted members of the community, nurses' opinions carry weight. We need to look past personalities, beyond our allegiances and group memberships, and emotional response. We need to weigh carefully what we hear before we believe, repeat, share or retweet. We need to think carefully, challenge the stories we hear and be more aware about the stories we share. As private individuals we can look for opportunities to be proactive, for example \#Standupforscience. As nurse scientists we need new skills. We certainly still need rigorous research accounts (don't stop submitting your manuscripts!) but the job is not finished there. We can learn from stories that go viral to craft messages that get beyond the journal webpage. Evidence remains essential for evidence-based healthcare, but we can adopt some 'post-truth' skills to improve how we disseminate information, for example, about effective diabetes self-management (Vas, et al. 2017) or new teaching and learning techniques (Kim, et al. 2017), to engage our communities' hearts as well as minds.

Professor Lin Perry

Editor in Chief, International Journal of Nursing Practice

Francis, R. (2013) Report of the Mid Staffordshire NHS Foundation Trust Public Inquiry. London. The Stationery Office.

Kim, H.S., Kim, M.Y., Cho, M-K, \& Jang, S.J. (2017) Effectiveness of applying flipped learning to clinical nursing practicums for nursing students in Korea: A randomized controlled trial. International Journal of Nursing Practice DOI: 10.1111/ijn.12574 
Vas, A., Devi, E.S., Vidyasagar, S., Acharya, R., Rau, N.R., George, A., Jose, T., \& Nayak, B. (2017) Effectiveness of self-management programmes in diabetes management: A systematic review. International Journal of Nursing Practice DOI: 10.1111/ijn.12571

The opinions expressed are those of the author alone. I acknowledge the thought-provoking Plenary 4 'Evidence in a post-truth world’, Global Evidence Summit, Cape Town Sept 2017. 